\title{
The Lifestyle and Halal Industry Methods with Local Culture: Study of Tourism and Halal Products in Nusa Tenggara Timur 2020
}

\author{
Ahmad Bahiej \\ Faculty of Sharia and Law, Universitas Islam Negeri Sunan Kalijaga Yogyakarta, \\ Indonesia, Jl. Marsda Adisucito Yogyakarta \\ E-mail: ahmad.bahiej@uin-suka.ac.id
Makhrus Munajat
Faculty of Sharia and Law, Universitas Islam Negeri Sunan Kalijaga Yogyakarta, Indonesia, Jl. Marsda Adisucito Yogyakarta \\ E-mail: makhrus@uin-suka.ac.id \\ Diky Faqih Maulana \\ Faculty of Sharia and Law, Universitas Islam Negeri Sunan Kalijaga Yogyakarta, \\ Indonesia, Jl. Marsda Adisucito Yogyakarta \\ E-mail: dikyfm@gmail.com
}

\begin{abstract}
The development of the tourism industry based on sharia principles has begun to attract the attention of Muslim tourists in various regions, so it needs to manage seriously and professionally. For example, in Labuan Bajo, Nusa Tenggara Timur is designated one of the four priority tourist destinations. So it is necessary to pay attention to the phenomenon that continues to develop at this time both at the local and global level, which makes halal tourism destinations a new alternative for the Muslim community to travel. This research is qualitative research with field studies and uses a legal and juridical sociology approach. By referring to several methods for conducting ijtihad, both individually and collectively, as is done by DSN-MUI with the concept of maslahah mursalah, istihsan or 'urf. The results of the study state that halal tourism is a development that cannot deny. This new concept has a benchmark as stated by the DSN-MUI with the principle of the United Nations provisions. Tourists in halal tourism not limited by differences in ethnicity, religion, race, and between groups. If there are restrictions, it is counterproductive or contrary to the essential nature of Islamic teachings that oriented to rahmatan lil 'alamin. So the halal tourism industry is an expression of the teachings of rahmatan lil 'alamin and a vehicle for friendship between people who are different in various aspects. It hope that halal tourism can develop to meet the needs of Muslim tourists so that they do not only visit conventional tourism, thus creating benefits.
\end{abstract}

Keywords: Halal tourism; tourism industry; Labuan Bajo.

The Lifestyle and Halal Industry Methods with Local Culture: Study of Tourism and Halal Products in Nusa Tenggara Timur 2020

Ahmad Bahiej, Makhrus Munajat \& Diky Faqih Maulana 


\section{INTRODUCTION}

Indonesia is a country with the largest Muslim population in the world (Lipka, 2017). According to data from the Central Statistics Agency in 2010, the Muslim population in Indonesia reached $207,176.162$ or $87.18 \%$ of the total population of Indonesia (BPS, 2010). However, not in all parts of Indonesia, Muslims make up the majority of the population. The provinces with the majority of the population are non-Muslims shown in the following table.

Table 1. Provinces with Minority Muslim Population Percentage

\begin{tabular}{rlrc}
\hline No. & Provinsi & Muslim & Non-Muslim \\
\hline 1. & Nusa Tenggara Timur & 9,05 & 90,95 \\
2. & Bali & 13,37 & 86,63 \\
3. Papua & 15,89 & 84,11 \\
4. & Sulawesi Utara & 30,90 & 69,1 \\
5. & Papua Barat & 38,40 & 61,6 \\
\hline
\end{tabular}

Source: Badan Pusat Statistik (BPS, 2010).

According to the State of the Global Islamic Economic Report 2018/19, Indonesia, although it has the largest halal market share globally, in the GIE, Indonesia index is still low in Southeast Asia. The Law on Halal Product Guarantee is the state's role in providing guarantees and protection regarding the halalness of products consumed by the public. For supporting these efforts, the Indonesian stateissued policies regarding the halal industry, such as Law Number 33 of 2014 concerning Guaranteed Halal Products and Law Number 21 of 2018 concerning Islamic Banking.

Table 2. Southeast Asian Countries Halal Industry Index

\begin{tabular}{ccccccc}
\hline No. & Countries & $\begin{array}{c}\text { Skor Indikator } \\
\text { GIE }\end{array}$ & $\begin{array}{c}\text { Halal } \\
\text { Food }\end{array}$ & $\begin{array}{c}\text { Halal } \\
\text { Travel }\end{array}$ & $\begin{array}{c}\text { Halal Media } \\
\text { and } \\
\text { Tourism }\end{array}$ & $\begin{array}{c}\text { Halal Medicine } \\
\text { and Cosmetics }\end{array}$ \\
\hline 1. & Malaysia & 127 & 81 & 92 & 61 & 96 \\
2. & Brunei & 45 & 58 & 26 & 37 & 57 \\
3. & Indonesia & 45 & 48 & 65 & 16 & 44 \\
\hline
\end{tabular}

Source: State of the Global Islamic Economy Report 2018/19 (Reuters \& Standard, 2018).

However, the industry and the halal lifestyle cannot separate from one's religion. Considering the minority Muslim population in several provinces in Indonesia, as shown in Table 1, it turns out that the guarantee of halal products in industry and lifestyle cannot take for granted. Therefore, there are still rejections of

The Lifestyle and Halal Industry Methods with Local Culture: Study of Tourism and Halal Products in Nusa Tenggara 


\section{Jurnal Ilmiah Al-Syir'ah Vol. 19, No. 1 (2021): 46-70 \\ Website: http://journal.iain-manado.ac.id/index.php/JIS ISSN 2528-0368 (online) ISSN 1693-4202 (print)}

the halal industry and lifestyle in some areas, even by local governments and figures or stakeholders in their regions (Keda, 2019). Several reasons can gather because it will lead to halal-haram discrimination, which is only known in certain religions and is contrary to the customs in an area.

One of the concerns with the declaration of the halal industry is that it will reduce tourism potential in East Nusa Tenggara. East Nusa Tenggara is an area with high tourism potential. With various tourism potentials stored in it, it is possible to make the tourism sector the leading sector of the economy in NTT. An increasing trend appears in tourist visits, an increase in the accommodation sector (hospitality and lodging), and the food and beverage supply sector (Rohman, 2019).

Based on table 1, East Nusa Tenggara is the province with a minor Muslim population, only $9.05 \%$. It is on this basis that this research finds its significance. This research will look for a meeting point between the demands for the halal industry and the halal lifestyle face the local culture and community culture in Muslim minority areas. As mandated by Article 5 of Law Number 33 of 2014 concerning Guaranteed Halal Products, the Ministry of Religion of the Republic of Indonesia is responsible for organizing halal product guarantees. Therefore, the Ministry of Religion of the Republic of Indonesia plays a role in providing guarantees and protection for the halal products consumed by the people in Indonesia's territory. Halal products guarantee the state insecurity regarding the public's halalness in all regions of the Republic of Indonesia. Halal products include industry, products, tourism, food, and others enjoyed by the community.

Meanwhile, there were rejections from several figures in East Nusa Tenggara towards halal tourism for several reasons, including a different local culture with halal requirements. For this reason, it is necessary to know and find common ground as a reconciliation of the conflict between halal demands and the culture of the people of East Nusa Tenggara. Therefore, this meeting point will become a role model for implementing halal product guarantees in several regions in Indonesia.

The halal industry and lifestyle, which is the central theme of this research, are limited to halal tourism and halal products. Halal products referred to in this study are limited to things that are halal consumed by the Muslim community. Meanwhile, the local culture referred to in this study is the culture or habits of the people of Nusa Tenggara related to behaviour or consumption that is contrary to the halal behaviour/product. Then how is the development of tourism and halal products in Nusa Tenggara Timur? What are the obstacles to the development of tourism and halal products in Nusa Tenggara Timur? And, what is the meeting point between tourism and halal products with local culture in East Nusa Tenggara?

This research is legal sociology research that uses the conflict theory framework from Ralf Dahrendorf. Conflict theory is a perspective that views society as a social system consisting of different interests in which there is an

The Lifestyle and Halal Industry Methods with Local Culture: Study of Tourism and Halal Products in Nusa Tenggara Timur 2020

Ahmad Bahiej, Makhrus Munajat \& Diky Faqih Maulana 


\section{Jurnal Ilmiah Al-Syir'ah Vol. 19, No. 1 (2021): 46-70 \\ Website: http://journal.iain-manado.ac.id/index.php/JIS ISSN 2528-0368 (online) ISSN 1693-4202 (print)}

attempt to conquer the other components to fulfil other interests or obtain the greatest good (Setiyawan, 2018). Ralf Dahrendorf argues that society consists of organizations based on power or authority. Power is defined as the domination of one party over another based on coercion, while management is defined as domination accepted and recognized by the dominant party. These relationships call imperatively coordinated associations because the interests of the two parties in these associations are different (Dahrendorf, 1959). The ruling party is interested in maintaining power, while the controlled party is interested in obtaining power that can cause social change. Thus, according to Dahrendorf, conflict is a source of social change (Sunarto, 2005).

In conflict theory, it states that conflict is needed to create social change. While structural-functional says that social change in society always occurs at the equilibrium point, conflict theory sees social instability caused by conflicts of interest. At some point, the community can reach a mutual agreement. Therefore, negotiations that carry out conflict in conflict create a consensus (Rosana, 2015). According to John Burton, as stated by Anthony de Reuck that resolving disputes can be done in three forms: first by finding alternative ways out of disputes (alternative dispute resolution), secondly by resolving conflicts through law and the authority of the ruling group (settlement), and thirdly through conflict resolution (de Reuck, 1990).

Several studies related to the halal industry and lifestyle have been carried out, including those conducted by Endang S. Soesilowati and Chitra Indah Yuliana. The title Comparison of Consumer Behavior of Halal Products in Muslim Majority and Minority Areas. This research conducted in Banten and Bali in 2009 and 2010 examines the comparison of Muslim consumer behaviour towards halal products located in Muslim majority and minority areas in terms of determinant factors and aspects of religiosity. The results of the research by Endang S. Soesilowati and Chitra Indah Yuliana stated that, in general, the attitude and perception aspects of behaviour control were the most dominant in the decision to consume halal food. Respondents in Bali have higher attitudes and perceptions of behavioural control in consuming halal food than in Banten. This data shows that by being a minority group in Bali, most of the population is Hindu. With a tendency to be more limited and challenging to obtain halal food, Muslims can be encouraged to have more attitude and control in deciding to consume only halal food (Soesilowati \& Yuliana, 2013).

Mohammad Jeffry Maulidi, in his research entitled Halal Tourism and Islamic Identity: A Case Study of Lombok, West Nusa Tenggara, discusses the implementation of Islamic sharia through halal tourism contributing to the condition of local communities on the island of Lombok. The results of Muhammad Jeffry Maulidi's researchers conclude that the attachment of Islamic identity only manifests in the symbolization of the construction of mosques and halal tourist destinations that do not or have not involved many local communities, the majority of whom are devout Muslims (Maulidi, 2019).

The Lifestyle and Halal Industry Methods with Local Culture: Study of Tourism and Halal Products in Nusa Tenggara 


\section{Jurnal Ilmiah Al-Syir'ah Vol. 19, No. 1 (2021): 46-70 \\ Website: http://journal.iain-manado.ac.id/index.php/JIS \\ ISSN 2528-0368 (online) ISSN 1693-4202 (print)}

A. Muchaddam Fahham also conducted similar research with the title Challenges of Halal Tourism Development in West Nusa Tenggara. This study describes the efforts and challenges faced by the NTB Regional Government in developing halal tourism in NTB. In his research, A. Muchaddam Fahham concluded that he was awarded the World's Best Halal Tourism. And the World's Best Halal Honeymoon Destinations. He also already has a legal umbrella to develop halal tourism. However, this does not mean that the NTB local government does not face various challenges.First, convincing its citizens about the urgency of tourism development. Halal certification in NTB. Second, the preparation of competent human resources. Third, acceleration of halal certification for hotels, restaurants, small and medium industries (IKM) and micro, small and medium company (MSMEs). Fourth, synergy between stakeholders in the halal certification process for IKM and MSMEs, and fifth, halal tourism has not support by a set of laws and regulations that allow synergies between stakeholders in the halal certification process (Fahham, 2017).

Based on the studies above and to the best of the author's knowledge, there has never been a study discussing the conflict between halal and culture, especially in East Nusa Tenggara and solutions or meeting points in halal identity with culture and customs in minority Muslim areas. Thus, this research expected to be a new idea in developing the halal industry and lifestyle in Indonesia's territory.

\section{RESEARCH METHODS}

The approach in this study is a qualitative approach that emphasizes the aspect of in-depth understanding of developmental problems, constraints, and the meeting point between tourism and halal products with local culture in East Nusa Tenggara. The qualitative research method used in this study is a case study, which is an in-depth study of tourism and halal products in East Nusa Tenggara within a certain time. The research subjects who are the source of data for this research are tourism businesses and halal products in East Nusa Tenggara and their stakeholders, including hotel/lodging owners, restaurants, food/beverage producers, Ministry of Religion and related regional officials.

This type of research data is field research data that takes data in Labuan Bajo, East Nusa Tenggara, which can be in the form of text, stories, photos, pictures, or artifacts. Data collected for this study using various methods, namely interviews with research subjects, documentation, and field observations. Interviews and observations are the main data collection techniques in this study. First, interviews conducted directly to research subjects/informants. In research observations, researchers observe tourism and halal products in East Nusa Tenggara to understand tourism and halal products. Meanwhile, documentation was done by collecting documents related to tourism and halal products in East Nusa Tenggara from books, archives, or reports.

The Lifestyle and Halal Industry Methods with Local Culture: Study of Tourism and Halal Products in Nusa Tenggara Timur 2020

Ahmad Bahiej, Makhrus Munajat \& Diky Faqih Maulana 
Jurnal Ilmiah Al-Syir'ah Vol. 19, No. 1 (2021): 46-70

Website: http://journal.iain-manado.ac.id/index.php/JIS ISSN 2528-0368 (online) ISSN 1693-4202 (print)

The data analysis technique in this study uses data analysis techniques as presented by Miles and Huberman, namely the Interactive Model divided into several steps. This first step is carried out by collecting interview data, documentation, and observations according to tourism and halal products in East Nusa Tenggara, developments and obstacles, and meeting points/reconciliation between tourism and halal products with local culture Nusa Tenggara Barat. This second step is done by sharpening, classifying, directing, removing unnecessary data and organizing the data to draw and verify conclusions. Finally, according to Miles and Huberman (1994), concluding is part of a complete configuration activity.

\section{RESULTS AND DISCUSSION}

\section{Geographical Labuan Bajo, Kec. Komodo, Kab. West Manggarai, Prov. East Nusa Tenggara}

Labuan Bajo located is in the district. Komodo, Kabupaten Manggarai Barat, Nusa Tenggara Timur Province. Kabupaten Manggarai Barat is one of the regencies on Flores Island, East Nusa Tenggara. Based on the Law of the Republic of Indonesia No. 8 of 2003, West Manggarai Regency was formed with the capital city of Labuan Bajo. Labuan Bajo is also one of the closest gateways for tourists who want to visit Komodo National Park. One of the eight directives from the President of the Republic of Indonesia, Joko Widodo, at the 2016 cabinet meeting, was to ensure progress in the field in 10 national tourist destinations or the so-called 10 New Balis, with Labuan Bajo as one of them (Meo, Sudiarta, \& Suwena, 2019).

Kabupaten Manggarai Barat consists of 12 sub-districts, namely Komodo, Boleng, Sano Nggoang, Mbeliling, Lembor, Welak, South Lembor, Kuwus, Ndoso, West Kuwus, Macan girlfriends, and girlfriends. In addition, Kabupaten Manggarai Barat has 3,141.47 km2 consisting of mainland Flores and several large islands such as Komodo, Rinca, Longos, and several other small islands (BPS, 2020).

Labuan Bajo is located on the west coast of Flores Island, East Nusa Tenggara. Labuan Bajo is located in Nusa Tenggara Timur, more precisely the westernmost tip of the island of Flores. Initially, Labuan Bajo was a village that developed into the capital of the Komodo District, West Manggarai Regency, East Nusa Tenggara Province. Geographically, the Labuan Bajo area is located at 80 13' South Latitude - 90 55' South Latitude and 119030 East Longitude - 1200 58' East Longitude, with an administrative area of $\pm 8,795 \mathrm{Ha}$ and a study area of $\pm 15,128$ $\mathrm{Ha}$ and most of the site is undulating land (Admin, 2019). Labuan Bajo's most sought after tourist destination is to travel to surrounding islands such as Padar Island, Rinca Island, Kelor Island, Kanawa Island and others.

The Lifestyle and Halal Industry Methods with Local Culture: Study of Tourism and Halal Products in Nusa Tenggara 


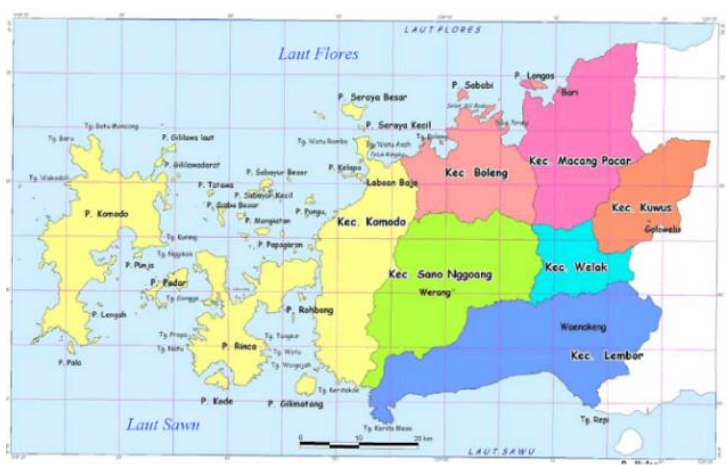

Figure 1. Map of Kabupaten Manggarai Barat

Komodo District, where Labuan Bajo is located, is the largest sub-district in West Manggarai Regency. More than a quarter of the area of Kabupaten Manggarai Barat is in the Komodo District (Wikipedia, 2020).

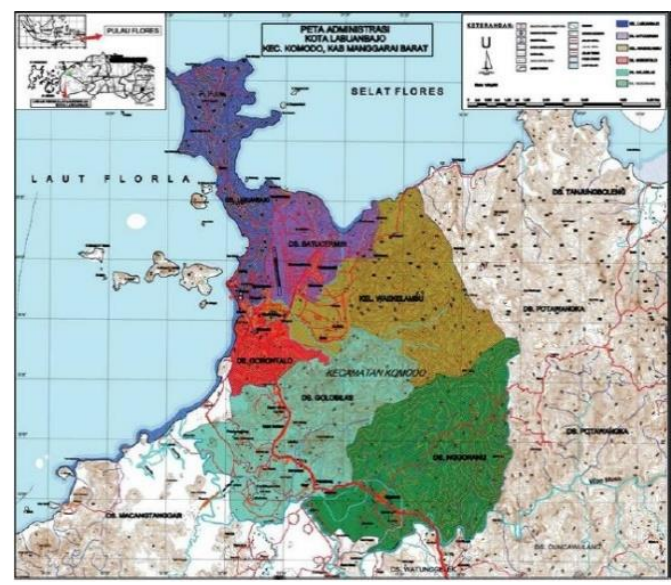

Figure 2. Labuan Bajo City

Labuan Bajo has 15 (fifteen) regions, namely: (1) Kampung Ujung, (2) Kampung Tengah, (3) Kampung Air, (4) Lamtoro, (5) Wae Kelambu, (6) Wae Medu, (7) Cowang Dereng, (8) Wae Kesambi, (9) Wae Bo, (10) Lancang, (11) Sernaru, (12) Wae Mata, (13) Pasar Baru, (14) Pede, and (15) Gorontalo (Wikipedia, 2020). Initially, Labuan Bajo was the capital of the Komodo District. However, during the division of Manggarai Regency into 2 (two) regencies, namely Manggarai Regency and West Manggarai Regency, Labuan Bajo was chosen to be the capital of West Manggarai Regency and made it as a functional city, not yet at the administrative stage and government authority. Meanwhile, the remaining subdistricts that still tend to be rural are still within the scope of the Komodo District.

The infrastructure and activities in the Labuan Bajo City area are considered quite advanced compared to those in other regions of Kabupaten Manggarai Barat. In the future, along with its role as the Regency Capital, the infrastructure and activities in the Labuan Bajo area will be more developed and more diverse (BAPPEDA, 2011). The Labuan Bajo urban area is located in the Komodo District, 


\section{Jurnal Ilmiah Al-Syir'ah Vol. 19, No. 1 (2021): 46-70 \\ Website: http://journal.iain-manado.ac.id/index.php/JIS ISSN 2528-0368 (online) ISSN 1693-4202 (print)}

one of 7 (seven) sub-districts in Kabupaten Manggarai Barat. Administratively, Komodo District consists of 3 (three) sub-districts and 14 (fourteen) villages. Initially, Komodo District consisted of 3 (three) sub-districts and 23 (twenty-three) villages.

\section{Social, Cultural, Economic, and Political Realities in Labuan Bajo, Nusa TenggaraTimur}

Tourism development also has an impact on the social life of local communities in the regions. If tourism development not run evenly and control by local governments, it will cause social problems, for example, if several people own land around tourism objects. And the high price of land resulted in seizures or claims from some people who considered their land. So far, the community believes that their land is not certified, but they understand that land is an ancestral heritage that has been handed down to them. This data is where social phenomena appear, and many people will feel that they also have the right to inherited land.

Culture will be first affected by tourism development; local people's habits will change as new cultural influences come. We know that where there is a tourism place that has a special attraction, it will invite domestic and international tourists to enter the area. Therefore, the need for socialization by the blood government to the local community that the location of regional privileges lies not only in tourism but local culture is also a determinant of regional progress (Toda, 2017).

Labuan Bajo is the centre of tourism activities in Kabupaten Manggarai Barat. Tourism consists of the tourism industry and tourist objects/attractions. Potential tourism objects include marine, nature, shopping and culinary tourism. Meanwhile, the tourism service business in Labuan Bajo began to increase after the election of Komodo National Park to become one of the seven wonders of the world. The development of tourism service businesses in Labuan Bajo includes souvenir entrepreneurs, travel bureaus and tourism associations, dive centres, travel agents, hotels or inns, restaurants or food stalls, and spas (reflexology).

In addition, people in Labuan Bajo work in tourism service businesses close to their places located in villages around Labuan Bajo such as Wae Kelambu Village, Gorontalo Village, Batu Cermin Village, and other nearby villages. Based on the Tourism Service Business spread in Labuan Bajo above, most local people work as private employees. Still, some open their businesses such as tourist boat rental services, rental services (motorcycles and cars), homestay managers and freelance guides.

The livestock sector also has the potential to improve the community's economy in the Labuan Bajo village. However, livestock farming is not much dominated by poultry farms with $92.82 \%$ of the total, followed by cattle farming at $3.31 \%$, goats at $1,46 \%$, Pig $1.99 \%$ and Buffalo $0.41 \%$. In addition, Labuan Bajo has a reasonably large sea area. So do not be surprised if some of the people of Labuan Bajo work as fishermen and fish farmers. The number of people who work

The Lifestyle and Halal Industry Methods with Local Culture: Study of Tourism and Halal Products in Nusa Tenggara 


\section{Jurnal Ilmiah Al-Syir'ah Vol. 19, No. 1 (2021): 46-70 \\ Website: http://journal.iain-manado.ac.id/index.php/JIS ISSN 2528-0368 (online) ISSN 1693-4202 (print)}

as fishers is 146 people, and fish farmers are 20 people. The fish income obtained by the fishermen is 25,550,058 tons per year. Thus, Labuan Bajo is a portrait that is quite promising to be managed and able to improve the standard of living of residents in Labuan Bajo Village (Agas, 2019).

The economic activities of the people closest to the Labuan Bajo Port are very varied. In the form of all community activities that have an impact on problems related to the economy in the form of meeting needs consisting of $25 \%$ carrying out economic activities or activities as fishermen, $13.33 \%$ as travelling traders, food sellers as much as $11.66 \%$, shop owners around $13.33 \%$, port workers around 10 $\%$, about $10 \%$ of port officers and another $10 \%$ work as motorcycle taxis. At the same time, the socio-economic conditions of the community seen from the education aspect are generally in the medium category with the public education level of $33.33 \%$ at the junior high school level and $33.33 \%$ at the high school education level, in the aspect of public health. Also, in the good category with the level of public health reaching $63.33 \%$, in the housing aspect, it is in the good category with a percentage level of more than $50 \%$ of the population who owns houses and semi-permanent houses. Permanent house. While the income aspect of the people around the Labuan Bajo port is relatively high, with an income of around Rp. 2,500,000 to Rp. 3,000,000 every month. And public expenditure is classified as moderate with an expenditure level of Rp. 1,000,000 - Rp. 1.350,000 per month (Firmansyah, Ramli, \& Surdin, 2019).

\section{Religious Life in Labuan Bajo, Nusa Tenggara Timur}

Bali is an example in the culture of its people has become part of the attraction of visiting the island. Therefore, local cultural values consciously guarded as part of identity. In Labuan Bajo, the community is developing dynamically. Along with regional economic growth, immigrants from various ethnic groups and nationalities came. This dynamic most clearly see in the restaurants around the city. There are meatball stalls, Makassar restaurants, and restaurants that offer Italian cuisine.

DPD member from NTT, Andreanus Garu, explained that the people of Labuan Bajo are used to mingling with immigrants. Marriage between them is also commonplace, and religious differences are not a barrier. On big days or religious events, people are used to helping each other. While many indigenous people choose to live in the interior and mountains, migrants choose to live in coastal areas by becoming fishermen or traders (Pambudy, 2017).

$66 \%$ of residents on the coast of Labuan Bajo are Muslim. However, residents in Labuan Bajo share every year, especially during Ramadan. The custom has boun since time immemorial. From the point of view of descent and marriage, they get along well. The uniqueness of this cohesiveness show by Catholics, Protestants, Hindus, and Buddhists in serving iftar menus for their Muslim brothers and sisters. 


\section{Jurnal Ilmiah Al-Syir'ah Vol. 19, No. 1 (2021): 46-70 \\ Website: http://journal.iain-manado.ac.id/index.php/JIS ISSN 2528-0368 (online) ISSN 1693-4202 (print)}

These various organizations and communities consisting of multiple ethnicities, tribes, and religions openly help alleviate and work in the humanitarian field. The action was carried out by helping to renovate mosques and places of worship for all faiths. This concern is built voluntarily with members. The Service for the renovation of areas worship free medical treatment and assisting orphanages. All members provide what the social environment needs (MI \& Lewar, 2018).

The life of the Bajo tribe is very close to the sea. The sea can view as a distinct culture (tradition) that refers to the relevant beliefs and practices that govern human life, including how these cultures are conceptualized, constrained, structured, and regulated. Like the medicinal culture of the Bajo tribe, it is a ritual (Nyanya Okang) to raise the spirits of the sick. There is no specific schedule or date for the ceremony; there is no agreement to program certain activities. The Bajo community in the area along the coast in Tilamuta District, Gorontalo Province, is a community with a strong tradition of worshipping the rulers of the sea and relating to requests for safety from various disasters (diseases). The Bajo people teach that humans and nature are in harmony, the masterpiece of God Almighty. Humans are symbols of the continuity and harmony of natural life as friends where life. Who are always filled with a light smile without a burden, living with nature without difficulty making a barometer of their love for nature in general, character means morals and good behaviour in living this life? Budha character is the mother of all ethics, manners, morals, good behaviour in relationships, work and daily life (Dai \& Manahung, 2020).

\section{Development of Tourism and Halal Products in Nusa Tenggara Timur}

The development of tourism in Labuan Bajo has existed since 1987 initially. In 1991 there was a trim level of tourist arrivals and few hotels until 2013 the Komodo sail was held, and until now, the number of tourist visits continues to increase. The development of tourism in the Labuan Bajo Village has an important role in increasing employment. We are encouraging the equal distribution of business opportunities, encouraging equitable national development, and contributing to the country's foreign exchange earnings generated from the number of foreign tourist visits and playing a role in alleviating poverty, which in turn will increase people's welfare. Tourism also plays a role in improving national identity and encouraging public awareness and pride in natural and cultural wealth (Alaman, 2012).

The tourist area of Labuan Bajo-Flores will develop as a world-class environmental tourism destination, and Labuan Bajo will be the entry point for tourists to NTT. Of the 500,000 foreign tourists, the government targets foreign exchange of IDR 8 trillion in 2019. Meanwhile, the target of local tourists visiting there at the end of 2019 is 5 million people (Pambudy, 2017). Therefore, the implementation of tourism development in Labuan Bajo Village, the Tourism and Culture Office of West Manggarai Regency, plays an important role in implementing integrated tourism development in regional development, which is

The Lifestyle and Halal Industry Methods with Local Culture: Study of Tourism and Halal Products in Nusa Tenggara 


\section{Jurnal Ilmiah Al-Syir'ah Vol. 19, No. 1 (2021): 46-70 \\ Website: http://journal.iain-manado.ac.id/index.php/JIS ISSN 2528-0368 (online) ISSN 1693-4202 (print)}

carried out in a systematic, planned, integrated, sustainable and responsible manner. while maintaining value. the value of local wisdom that lives in the community, environmental sustainability and quality as well as increasing the prosperity and welfare of the community. The development of tourism has become commonplace in the lives of traders in Labuan Bajo, this is evidenced by the emergence of a symbiotic relationship of mutualism that causes people not to feel foreign to tourism activities. It also encourages people to continue to market local products such as songket woven fabrics and Komodo statues to tourists. In addition, developments have also changed the work of local communities. The development of tourism in Labuan Bajo also creates enormous opportunities and employment opportunities, such as; culinary entrepreneurs, sculpture craftsmen, woven cloth sellers, hotel employees, restaurant employees, stall businesses. Based on the results of interviews with traders, they found that their main income was from tourism, such as from weaving and sculpture. Some others (vegetable traders) said that their income comes from selling vegetables, but most of the families of these traders work in the tourism industry (Agas, 2019).

As the main premium-class tourist destination, Labuan Bajo, Manggarai Barat, Nusa Tenggara Timur (NTT) continues to improve. Starting from infrastructure development that continues to be accelerated to waste management issues. The main focus of the waste problem in Labuan Bajo is the beach and road reclamation. However, garbage is still disposed of carelessly by residents and business actors who live around tourist sites. The perception of the impact of waste management on tourism sustainability in Labuan Bajo, viewed from the ecological aspect, proves that tourism development in this region still requires more intensive intervention in the environmental dimension. It can be said that the status of tourism sustainability in terms of environmental management in Labuan Bajo is in a state of quiet sustainability (Leha, Wolo, Marselina, \& Parera, 2020).

\section{Obstacles of the Development of Tourism and Halal Products in Nusa Tenggara Timur}

As a city centre that has worked on tourism as a leading sector, in Labuan Bajo, there are also so many tourist accommodations and tourism service businesses with local and non-local ownership. This situation has an impact on the socioeconomic conditions of the Labuan Bajo community. Most of the Labuan Bajo workforce people work in the tourism sector, followed by government agencies, the fisheries sector, and agriculture (Sugiarto \& Mahagangga, 2020).

There are $23 \%$ of tourism developments that have given saturation to the community. Most people who feel bored are woven cloth traders, pearl traders, and dragon statue traders. The saturation is because the work of these traders depends on the arrival of tourists, where the traders have to wait for tourists to buy the merchandise they sell. The traders admitted that the peak of saturation occurs in the

The Lifestyle and Halal Industry Methods with Local Culture: Study of Tourism and Halal Products in Nusa Tenggara Timur 2020

Ahmad Bahiej, Makhrus Munajat \& Diky Faqih Maulana 


\section{Jurnal Ilmiah Al-Syir'ah Vol. 19, No. 1 (2021): 46-70 \\ Website: http://journal.iain-manado.ac.id/index.php/JIS ISSN 2528-0368 (online) ISSN 1693-4202 (print)}

low season, where the traders have to wait for tourists for less than 15 hours in one day with very little income and sometimes do not earn in a day.

Meanwhile, during the peak season, the boredom felt during the low season paid off. So with that, the traders expect the government to open a special place to sell local handicrafts and weaving so that tourists can reach them more easily. In addition, tourism is growing, and the tourism sector as the main sector of the local community's economy has become a dilemma because it has an impact that disturbs the community.

According to the study results, $49 \%$ of respondents also felt the impact of tourism development. These impacts include (Agas, 2019); a) changes to the lifestyle of the younger generation in Labuan Bajo (style of dress and style of language); b) the emergence of unfair competition between communities (competing for each other); c) the loss of local cultural values (more following the culture of outsiders); d) people's lifestyles become more consumptive, and; e) lack of communication between communities due to work.

However, the local community realizes that the changes in Labuan Bajo are a consequence of the development of tourism, and everything must be carried out in tandem. Labuan Bajo is located in Nusa Tenggara Timur, more precisely the westernmost tip of the island of Flores. Labuan Bajo's most sought after tourist destination is to travel to surrounding islands such as Padar Island, Rinca Island, Kelor Island, Kanawa Island and others. Transportation sea is needed to support the activities, but ship managers in Labuan Bajo still do not understand the efforts to prevent marine pollution. Therefore, tourism activities need to preserved for the safety of tourism activities, such as preventing air pollution caused by exhaust emissions on ships (Pratiwi \& Pratama, 2020).

In addition to the negative impacts above, tourism development also increases the development of tourism and public infrastructure, facilities and infrastructure. Since selecting the Komodo dragon as one of the world heritages and becoming one of The New Seven Wonders by UNESCO and Sail Komodo in 2013, the central and local governments have begun to build various infrastructures and facilities to make it easier for investors and tourists to come to Labuan. Bajo (Alaman, 2012).

Forms of infrastructure such as; roads, ports (public and tourism), airports, hospitals, health centres, while tourism facilities and infrastructures such as hotels, restaurants, cafes, bars, money changers, dive centres, tourism information centres (TIC), interpretation boards, souvenir shops, travel agents, tour buses, tour boats and others. These developments aim to provide convenience for tourists and investors and accelerate economic equity in the community in Labuan Bajo. But, on the other hand, people think that this is still lacking. Such as the construction of a special place for selling local works such as woven fabrics, pearls, typical Labuan Bajo handicrafts, internet networks and the construction of local cultural performance venues.

The Lifestyle and Halal Industry Methods with Local Culture: Study of Tourism and Halal Products in Nusa Tenggara 


\section{Jurnal Ilmiah Al-Syir'ah Vol. 19, No. 1 (2021): 46-70 \\ Website: http://journal.iain-manado.ac.id/index.php/JIS ISSN 2528-0368 (online) ISSN 1693-4202 (print)}

In addition, parking area facilities still require an open area because almost all activities cause increasingly widespread problems. The parking area obtained is more fulfilling because the more significant the traffic capacity that is active either leaving or going to the centre of activity, the greater the need for parking space. The unbalanced area of the existing road is where the vehicle capacity is. Then there are shops, trade centres and various other buildings that were built without parking. One of the factors that cause vehicle congestion in Labuan Bajo is the lack of parking space, dense vehicle volume, indecisive rules and people who do not understand the rules (Fantura, Wijaya, \& Subamia, 2020).

\section{Conflict of Halal Products in Tourism with Local Culture}

Religious leaders in Labuan Bajo stated that tourism had become a new paradigm for the community after the designation of Komodo as a national park by UNESCO in 1987, then continued with the designation of Komodo national park as one of the seven wonders of the world, followed by the Komodo sail activity in 2013. During the trip, they were very receptive to tourism because it had brought changes to the community environment in Labuan Bajo. The majority of religious leaders support the development of the tourism industry. The presence of investors also encourages the progress of the regional economy and society in Labuan Bajo.

But on the other hand, this tourism development has caused much land in Labuan Bajo to be sold. On the other hand, the long-term effect of tourism in Labuan Bajo also provides enormous benefits for the people of Labuan Bajo and its surroundings. The benefits include employment opportunities (hotel employees, restaurant employees, tour crew members, bar employees, and SPA employees). In addition, there are business opportunities such as transportation rental services (tour boats, motorbikes, and cars), travel agent entrepreneurs (land tours and diving), homestay entrepreneurs, traders (culinary, woven fabrics, pearls, dragon statues and other handicrafts).

Relationships between communities are interdependent. From the community side, they see that tourism is the primary source of income. Still, from the investors and tourists perspective, the availability of the community in accepting their presence is important, in this case, security and comfort. As a result of this relationship, it creates an attitude where people no longer feel foreign and are no longer reluctant to tourism. Still, rather intense communication exists between the two. Therefore, there is an important role to play in raising the awareness of tourism in the community.

In addition, religious leaders' role is to make people aware so that outside cultures do not influence them. Unfortunately, seeing the people of Labuan Bajo consider tourism a normal thing, it has plunged them into negative changes such as people starting to depend on tourism, followed the tourist lifestyle, lost culture, and people began to ignore the environment.

The Lifestyle and Halal Industry Methods with Local Culture: Study of Tourism and Halal Products in Nusa Tenggara Timur 2020

Ahmad Bahiej, Makhrus Munajat \& Diky Faqih Maulana 


\section{Jurnal Ilmiah Al-Syir'ah Vol. 19, No. 1 (2021): 46-70 \\ Website: http://journal.iain-manado.ac.id/index.php/JIS ISSN 2528-0368 (online) ISSN 1693-4202 (print)}

Local religious leaders explained that the tourism industry had become an important sector for the economy of the people of Labuan Bajo and its surroundings. These people are workers in the tourism industry, such as hotels, restaurants, cafes, bars, money changers, travel agents, transportation service providers, traders, etc. In terms of tourism marketing, respondents stated that tourism marketing has been going very well. The evidenced by the many investors and tourists who come and invest in Labuan Bajo. Tourism marketing results in the loss of local culture.

Meanwhile, in planning, most religious leaders admitted that they did not support the tourism development plan carried out by the government. The essential thing that local leaders do not support is the provincial government's lack of attention to tourism development. The development of tourism in Labuan Bajo is only profit-oriented, while on the other hand, local culture is getting lost. Respondents admitted that the development of tourism in Labuan Bajo had received a rejection from the community in this case: religious leaders, cultural leaders, communities, and some from the district. The refusal was made not because of tourism but related to government policies that contradict the needs of local communities.

The form of refusal made by respondents and the community is demonstrations and discussions with the government. The demos that have been done such as; Policies for hotel development in the beach public area, policies for increasing ticket prices for Komodo national parks, policies for developing rest areas on conservation lands for Komodo national parks.

Meanwhile, discussions were held regarding ferries that carry tourists to the Komodo National Park at very low prices. The refusal was not due to tourism but a policy that was deemed inappropriate by the government. So with that, the community admits that they need to establish regulations regarding live on board and policies to increase the price of admission to Komodo National Park (Mammlianus, 2018).

\section{Reconciliation of Tourism and Halal Products with Local Culture in Labuan Bajo, East Nusa Tenggara}

The Bajo tribe is a tribe originating from the Sulu archipelago, Southern Philippines, which then sailed to Sulawesi to East Nusa Tenggara and stopped at what is now Labuan Bajo. There are many exciting things about the Bajo tribe that can be seen, one of which is the status of this tribe as immigrants, not natives of the Flores ethnicity. Still, uniquely they are the foundation stone of the Labuan Bajo area.

This tribe itself has always adhered to Islam, and since coming to the island of Flores until it became a tourist area, this tribe continues to live in harmony with other tribes who are Christian. This tribe itself still respects the customs and culture of the indigenous tribes as residents of the island of Flores. On the other hand, the

The Lifestyle and Halal Industry Methods with Local Culture: Study of Tourism and Halal Products in Nusa Tenggara 


\section{Jurnal Ilmiah Al-Syir'ah Vol. 19, No. 1 (2021): 46-70 \\ Website: http://journal.iain-manado.ac.id/index.php/JIS ISSN 2528-0368 (online) ISSN 1693-4202 (print)}

indigenous Flores tribe also respects this tribe as an immigrant, so that the name Bajo is also used as a village name (Admin, 2019).

The development of an Islamic identity character can represent a just development and provide an example of a 'peaceful' face of Islam. Its people can interact in a pluralistic world society without losing their identity as Muslims. For the local community themselves, understanding Islam and the attachment of Islamic identity is important for the sustainability of generations.

A dynamic and progressive mind built through Islamic identity character education has a vital role in forming good character. In addition, good manners are essential for inculcating moral values and social values in the tourism industry community because the influence of globalization has an impact on the depletion of ethics, including courtesy and the neglect of local community structures to pursue economic gains (Maulidi, 2019).

Labuan Bajo has various potential natural resources for tourism but not yet fully managed and developed so that tourism activities have not run optimally. However, the questionnaire results in the study by Khan and his colleagues showed that all respondents stated that there are natural resources in the Labuan Bajo area that can use as an attraction for tourists (Khan et al., 2020).

The government has designated Labuan Bajo as one of four priority tourist destinations and Lake Toba, Borobudur, and Mandalika. However, of the four priority areas, Labuan Bajo is the area with the least number of tourist visits, although Labuan Bajo has its uniqueness with its Komodo dragons (Komalasari \& Ganiarto, 2019). Overall, of the four tourist destinations (Borobudur Temple, Mandalika, Labuan Bajo and Lake Toba) promoted by the government, respondents perceive Labuan Bajo as the most attractive destination and have the most beautiful scenery and natural attractions. In addition, the effective image of the destination is higher than the cognitive image, where respondents see more of the atmosphere and comfort that tourist destinations can provide compared to the uniqueness of the tourist attraction itself (Irena, Christie, \& Thio, 2019).

The development of the tourism industry based on sharia principles is currently starting to attract the attention of Muslim tourists in various regions, so it needs to be managed seriously and professionally. Therefore, by observing the phenomenon that continues to develop today, both at local and global levels, which makes halal tourism destinations a new alternative for the Muslim community to travel, it is necessary to explore its juridical basis from an Islamic perspective (Djakfar, 2017).

In fact, in 2016, the National Sharia Council (DSN) MUI fatwa issued Fatwa Number 108/DSN-MUI/X/2016 concerning Guidelines for Tourism Implementation based on sharia principles which are the basis for standardizing aspects of halal tourism. However, it seems that this fatwa is still not final and still

The Lifestyle and Halal Industry Methods with Local Culture: Study of Tourism and Halal Products in Nusa Tenggara Timur 2020

Ahmad Bahiej, Makhrus Munajat \& Diky Faqih Maulana 


\section{Jurnal Ilmiah Al-Syir'ah Vol. 19, No. 1 (2021): 46-70 \\ Website: http://journal.iain-manado.ac.id/index.php/JIS ISSN 2528-0368 (online) ISSN 1693-4202 (print)}

needs improvement so that in the future, new ijtihad products still need to meet the wider community's needs. Of course, the new ijtihad is in line with the development of halal tourism itself to ensure legal certainty in the tourism world.

Linguistically, ijtihad means earnestly pouring out one's mind, spending one's ability. Meanwhile, it interprets by devoting existing abilities in discussing a problem to get a difficult law starting from the Book and Sunnah (Muhammad, 2007). Or, in other words, ijtihad is an attempt to formulate legal lines or rules whose regulations not contained in the two primary sources of Islamic law (Muhammad, 2007).

There are several methods for conducting ijtihad in Islamic law, both individually and collectively, as is done by the DSN-MUI. Among the methods referred to are ijmak, qiyas, istidal, al-masalih al-mursalah (maslahat mursalah), istihsan, istishab, and 'urf (Muhammad, 2007). In the future, halal tourism needs to be developed to meet the needs of Muslim tourists so that they do not only visit conventional tourism. In that case, the basis for consideration is to create benefits.

The following provisions will put forward Fatwa Number 108/DSNMUI/X/2016. First, tourist destinations must direct efforts to: realize the general benefit and good; enlightenment, refreshment and calming; maintain trust, safety and comfort; maintain cleanliness, nature conservation, sanitation and the environment; and respecting socio-cultural values and local wisdom.

Second, tourist destinations must have: worship facilities suitable for use, easy to reach, and meet sharia requirements. And third, the destination must avoid polytheism and superstition, immorality, adultery, pornography, liquor, drugs and gambling, art and cultural performances, and attractions contrary to sharia principles.

The fiqh provisions have formulated through ijtihad conducted by the National Sharia Council under the auspices of the Indonesian Ulema Council. This institution already has the authority related to the establishment of sharia law in Indonesia, which should be used as a guideline by the wider community (Djakfar, 2017). Tourism development should be able to be built and developed based on the principles of sustainable development. According to the United Nations, these principles are (Nations, 2002):

a. Tourism development must be able to be built by involving local communities. The vision of tourism development should design based on the ideas of local communities and for the welfare of local communities. Local people should be actors, not spectators.

b. It was creating a balance between the needs of tourists and the community. The importance of community economic empowerment is a goal based on a willingness to shape the quality of destinations expected by tourists.

c. Development must involve stakeholders, and involving more parties will get better input.

The Lifestyle and Halal Industry Methods with Local Culture: Study of Tourism and Halal Products in Nusa Tenggara 


\section{Jurnal Ilmiah Al-Syir'ah Vol. 19, No. 1 (2021): 46-70 \\ Website: http://journal.iain-manado.ac.id/index.php/JIS ISSN 2528-0368 (online) ISSN 1693-4202 (print)}

d. They are providing convenience to local entrepreneurs on a small and medium scale. Educational programs related to tourism should prioritize the local population, and the growing industry in the area should be able to accommodate as many local workers as possible.

e. Tourism must generate other businesses in the community, meaning that tourism must have a multiplier impact on other sectors, both new companies and businesses that have developed at this time.

f. There is a cooperation between local communities as creators of tourist attractions and operators selling tour packages, so building mutually beneficial cooperative relationships is necessary. For example, the development of dance studios, farmer groups, and others because they benefit from the development of the tourism sector.

g. Tourism development must ensure sustainability, provide benefits for the current community and not harm future generations.

h. Tourism must grow on the principle of optimization, not exploitation

i. There must be periodic monitoring and evaluation to ensure tourism development continues to run within the concept of sustainable development,

j. There must be openness to using resources such as underground water, land use, and other resources that must ensure that they are not misused.

k. Carry out human resource improvement programs in the form of education, training, and certification for tourism expertise. So that it can be ensured that workers are ready to work by the job descriptions that have been set by their respective fields so that the certification program will be the right choice.

1. The realization of three qualities, namely tourism, must realize the quality of life of the local community.

Sustainable tourism development or Sustainable Tourism Development according to Yemen and Mohd with 4 conditions (Amat \& Abdullah, 2004), namely; a) community members must participate in the tourism planning and development process; b) education for hosts, industry players and visitors/tourists; c) wildlife habitat quality, energy use and microclimate must be understood and supported, and; d) investment in alternative forms of transportation.

Following up that there are $17 \%$ of the community reacted against tourism. The refusal is not because the community does not accept tourism but is related to the policies made by the government. This policy makes people disagree, which leads to rejection. The form of refusal was in the form of demonstrations against the government. Some of these policies include the closure of the Komodo National Park, the increase in entrance ticket prices at Komodo National Park, the rejection of ferries operating to Komodo National Park, the development of hotels on Pede Beach, the development of rest areas in Komodo National Park, and the rejection of the Labuan Bajo BOP. The community considers that the policies made by the

The Lifestyle and Halal Industry Methods with Local Culture: Study of Tourism and Halal Products in Nusa Tenggara Timur 2020 


\section{Jurnal Ilmiah Al-Syir'ah Vol. 19, No. 1 (2021): 46-70 \\ Website: http://journal.iain-manado.ac.id/index.php/JIS ISSN 2528-0368 (online) ISSN 1693-4202 (print)}

government are only for the benefit of some people, without thinking about the needs of the local community (Mammilianus, 2018).

Halal tourism in the systematics of Islamic teachings is included in muamalah studies, which regulates the interaction between one human being and another human being universally. Universal here means that in doing muamalah it is not limited by narrow SARA issues that are potentially exclusive, which are less profitable in business. Therefore, tourists in halal tourism are not limited by differences in ethnicity, religion, race, and between groups. If there are restrictions, it is counterproductive or contrary to the basic nature of Islamic teachings, which are rahmatan lil 'alamin for all life in the world. Isn't the halal tourism industry an expression of the teachings of rahmathan lil 'alamin and a vehicle for conducting friendships between different people in various aspects (Djakfar, 2017).

In this case, the analysis of mashlahah and its relationship with society can use, namely mashlahat al-kulliyah and mashlahat al-juz'iyyah. The first mashlahah is mashlahah that returns to society in general (broad). At the same time, the second mashlahah is mashlahah for individuals or several individuals that must be maintained according to the provisions of muamalah (Al-Hasaini, 1995). In the maslahah aspect, the presence of halal tourist destinations expected to provide many benefits to all levels of society in a broad sense, both for entrepreneurs, the community, and visitors, which will ultimately increase local revenue (PAD). This increase in PAD will eventually impact the residents' welfare where halal tourism destinations are developed (Pitana and Gayatri, 2005: p. 109). Furthermore, the increasing number of visitors is an indicator that visitors are satisfied with all kinds of objects that are presented with all the supporting factors. Therefore, if reality shows so, then both kulliyah and juz'iyyah, halal tourist destinations, can benefit the wider community.

Regarding the products circulating in the community, not all of them are guaranteed halal, according to sharia. Therefore, the regulation regarding the halalness of a product, legal certainty is also not guaranteed, so it needs to be regulated in national legislation. That is the primary consideration that became the reason for the birth of the Law of the Republic of Indonesia Number 33 of 2014 concerning Guaranteed Halal Products in Indonesia, as stated in the weighing clause. Because this law, in general, of course, also applies to the halal tourism industry, which must be sterile from all things that are haram based on sharia. The relevance of the law to halal tourism, among others, is because it touches the various needs of (Muslim) tourists such as lodging, restaurants, swimming pools, spas and other supporting factors. While at the hotel, they treat food and drinks according to the facilities provided, all of which must be guaranteed halal (Fatwa of the MUI National Sharia Council No. 108/DSNMUI/X/2016 concerning Guidelines for Tourism Implementation Based on Sharia Principles., 2016).

However, the most important thing in the law's birth is ensuring legal certainty for the community. If legal certainty is guaranteed, then legal subjects will

The Lifestyle and Halal Industry Methods with Local Culture: Study of Tourism and Halal Products in Nusa Tenggara 


\section{Jurnal Ilmiah Al-Syir'ah Vol. 19, No. 1 (2021): 46-70 \\ Website: http://journal.iain-manado.ac.id/index.php/JIS \\ ISSN 2528-0368 (online) ISSN 1693-4202 (print)}

feel safe, peaceful, calm, and comfortable to carry out legal actions about tourism activities because they are free from doubts about the threat of punishment that will be received.

Therefore, in Article 3, it is emphasized that the implementation of JPH aims to provide comfort, security, safety, and certainty of the availability of halal products for the public in consuming and using products and increasing added value for business actors to produce and sell halal products.

Indeed, the understanding of mukhalafah implied in article three above is definitely to create legal certainty for the public in consuming a product, whether in the form of food, drink, or cosmetic tools because these three products are needed a lot, so many products and sold to meet market needs.

Thus, the Halal Product Guarantee (JPH) law will benefit not only producers but also consumers. Furthermore, in the world of tourism, this law benefits stakeholders and Muslim tourists in protecting their beliefs. This JPH the goal to be achieved by the presence of a law on JPH which is basically to protect the Muslim community from all things that are counterproductive to Shari'a's principles. Likewise, activities in the world of tourism are predicated as halal.

Complying with the provisions of the JPH is the same as making efforts to develop halal tourism that truly based on sharia principles. Isn't the presence of this law a form of government responsibility in participating in guarding the protection of the religious security of the community in life. For this reason, halal tourism business actors must also be responsible for their implementation by developing halal tourist destinations, which have been their activities (Djakfar, 2017).

Likewise, about the problem of human resources in their function as khalifatullah, not a few roles are played on this earth (Qardhawi, 1995). Among other things, as actors in tourism activities in a broad sense, thus, in playing their role, they must prioritize applicable legal and ethical values.29 In a sense, proactively protecting the tourism community as stated in the Act. Regarding Halal Product Guarantee and Consumer Protection (Djakfar, 2017) as taught in the basic concept of maqashid al-syariah in Islam.

Religious diversity, in this case, the people of Labuan Bajo, who for most of their lives have depended on the realm of tourism, which will indirectly mingle with tourists from various ethnicities, tribes and cultures. By considering some of the principles of sustainable development from the United Nations, four signs of sustainable tourism development or Sustainable tourism development according to Yemen and Mohd, the concept of mashlahah in Islam and the Law on Guaranteed Halal Products. So elements of the Labuan Bajo community need to prioritize and maintain Islamic values and local wisdom.

The Lifestyle and Halal Industry Methods with Local Culture: Study of Tourism and Halal Products in Nusa Tenggara Timur 2020 


\section{Jurnal Ilmiah Al-Syir'ah Vol. 19, No. 1 (2021): 46-70 \\ Website: http://journal.iain-manado.ac.id/index.php/JIS ISSN 2528-0368 (online) ISSN 1693-4202 (print)}

As for what is meant by Islamic values, it can interpret moral values (ethics) that must apply in various aspects of life. For example, wasn't the mission of the Messenger of Allah, among them, to perfect human morals? Therefore he should be uswah for humanity. As Nabiyallah and Rasulullah saw in his capacity, he has the greatness of character as praised by Allah SWT in the holy book al-Qur'an alKarim. One of the tips for his success in carrying out his holy mission of prophecy is because of the greatness of morality that should be an example in life (Amin, 1975). In managing the halal tourism industry, you must avoid everything that is counter-production with sharia values which will ultimately injure the meaning of halal itself (Fatwa of the MUI National Sharia Council No. 108/DSNMUI/X/2016 concerning Guidelines for the Implementation of Tourism Based on Principles Sharia, 2016).

Likewise, those related to local wisdom values are no less significant than values derived from religion. This local wisdom is not only a potential selling point because of its uniqueness and character. However, it contains philosophical values or views of life that are inherent and become the life guides of their respective communities. Local traditions in the treasures of Islamic law are known as 'urf. And in Islam, this value is included in 'urf sahih. Because it can be used as a source of law with a note that it has beneficial value, is generally accepted, is acceptable to common sense, and does not conflict with the shari'a arguments (Taufiqurrahman, 2018).

Several application recommendations make it easier for visitors when travelling, including the Marine Tourism Map (PWB). PWB was created and recommended by Hydro-Oceanographic Engineering Study Program Students, STTAL, to provide information about tourist sites in the Labuan Bajo area. Some icons or symbols are easily recognizable and accompanied by brief information about the place and a means of supporting aids in navigating the cruise. Thus, making it easier for tourists to determine existing tours that will be. In addition, the appropriate marine tourism map for the Labuan Bajo and Komodo Island areas can be used effectively by users and tourist ships (Widianto et al., 2019).

In addition, Leonardo Jeffry Sutedjo and Rinabi Tanamal recommend an application for tourists in Labuan Bajo using the Forward Chaining method. This application can help tourists find excellent places to travel. Because the user's purpose of travelling is to have fun, if the user is confused about determining the existing location, this application will assist the user in determining the desired tourist spot. This application also provides several tourist options, such as tours in the sea, cities, or hills/mountains (Sutedjo \& Tanamal, 2020). Applying several application recommendations to make it easier for visitors when travelling is the implication of istihsan. Istihsan is a method of taking the Hanafi school of law that needs to develop in progressive Islamic law. Islamic law in the industrial era 4.0 leads to digitalization and the transformation of ways of transacting in the economy. Therefore, Islamic economics, as the development of muamalat fiqh should use this

The Lifestyle and Halal Industry Methods with Local Culture: Study of Tourism and Halal Products in Nusa Tenggara 


\section{Jurnal Ilmiah Al-Syir'ah Vol. 19, No. 1 (2021): 46-70 \\ Website: http://journal.iain-manado.ac.id/index.php/JIS ISSN 2528-0368 (online) ISSN 1693-4202 (print)}

method to solve contemporary problems of the industrial era 4.0 (Nur'aini \& Ngizzul, 2020), including in halal tourism.

\section{CONCLUSION}

The development of the tourism industry based on sharia principles is currently starting to attract the attention of Muslim tourists in various regions, so it needs to manage seriously and professionally. Therefore, by observing the phenomenon that continues to develop today, both at local and global levels, which makes halal tourism destinations a new alternative for the Muslim community to travel, it is necessary to explore its juridical basis from an Islamic perspective. There are several methods for conducting ijtihad in Islamic law, both individually and collectively, as is done by the DSN-MUI. Among the methods referred to are ijmak, qiyas, istidal, al-masalih al-mursalah (maslahat mursalah), istihsan, istishab, and 'urf. In the future, halal tourism needs to be developed to meet the needs of Muslim tourists so that they do not only visit conventional tourism. In that case, the basis for consideration is to create benefits.

Halal tourism is a development that cannot die. This new business has benchmarks as stated by DSN-MUI with the principle of United Nations provisions. Tourists in halal tourism not limited by differences in ethnicity, religion, race, and between groups. If there are restrictions, it is counterproductive or contrary to the basic nature of Islamic teachings, which are rahmatan lil 'alamin for all life in the world. Isn't the halal tourism industry an expression of the teachings of rahmathan lil 'alamin and a vehicle for conducting friendships between different people in various aspects?

\section{ACKNOWLEDGMENTS}

The researcher would like to thank all parties who have been involved in this research. Especially the support and funding from the SBKU-Based Competitive Research (Standard Cost of General Output) Research and Development Center for Religious Guidance and Religious Services of the Ministry of Religion of the Republic of Indonesia with the theme of Lifestyle and Contemporary Issues of Halal Products. Of course, thanks also to the reviewers and managers of the Al Syir'ah Scientific Journal of IAIN Manado for processing our articles.

\section{REFERENCES}

Admin. (2019). Informasi Menarik Suku Asli Labuan Bajo Flores Untuk Anda. Retrieved from Labuan Bajo Tour website: https://labuanbajotour.com/wisata/informasi-tentang-suku-asli-labuan-bajo

Agas, K. (2019). Respon Masyarakat dalam Perkembangan Pariwisata di Kelurahan Labuan Bajo, Kabupaten Manggarai Barat Provinsi Nusa

The Lifestyle and Halal Industry Methods with Local Culture: Study of Tourism and Halal Products in Nusa Tenggara Timur 2020

Ahmad Bahiej, Makhrus Munajat \& Diky Faqih Maulana 


\section{Jurnal Ilmiah Al-Syir'ah Vol. 19, No. 1 (2021): 46-70 \\ Website: http://journal.iain-manado.ac.id/index.php/JIS ISSN 2528-0368 (online) ISSN 1693-4202 (print)}

Tenggara Timur. Sekolah Tinggi Pariwisata Bandung.

Al-Hasaini, I. (1995). Nadariyat al-Maqashid 'Inda al-Imam Muhammad al-Tahir ibn 'Asyur. Al-Ma'had al-Islami li al-Fikr al-Islami.

Alaman, A. (2012). Sail Komodo dan Pemberdayaan Ekonomi NTT (1). Retrieved from Pos-Kupang.com website: https://kupang.tribunnews.com/2012/10/12/sail-komodo-dan-pemberdayaanekonomi-ntt-1

Amat, R. Y., \& Abdullah, M. (2004). Community-based ecotourism: a new proposition for sustainable development and environmental conservation in Malaysia. Journal of Applied Sciences, 4(4), 583-589.

BAPPEDA. (2011). Laporan Akhir Penyusunan Master Plan Air Minum Bersih dalam Kota Labuan Bajo Kabupaten Manggarai Barat Provinsi Nusa Tenggara Timur Tahun Anggaran 2011. Maggarai Barat.

BPS. (2010). Kewarganegaraan, Suku Bangsa, Agama, dan Bahasa Sehari-hari Penduduk Indonesia: Hasil Sensus Penduduk 2010.

BPS. (2020). Kabupaten Manggarai Barat dalam Angka 2020. Maggarai Barat.

Dahrendorf, R. (1959). Class and conflict in industrial society. Stanford University Press.

Dai, F., \& Manahung, R. (2020). Kearifan Lokal Masyarakat Suku Bajo Studi Etnografi Nilai-Nilai Pendidikan Agama Islam dan Budi Pekerti Pada Praktek Ritual Keagamaan di Desa Bajo Kecamatan Tilamuta. PEKERTI, 2(1), 41-57.

de Reuck, A. (1990). A theory of conflict resolution by problem-solving. In Conflict: Readings in management and resolution (pp. 183-198). Springer.

Djakfar, M. (2017). Pariwisata halal perspektif multidimensi: peta jalan menuju pengembangan akademik \& industri halal di Indonesia. UIN Maliki Press.

Fahham, A. M. (2017). Tantangan Pengembangan Wisata Halal di Nusa Tenggara Barat. Aspirasi: Jurnal Masalah-Masalah Sosial, 8(1), 65-79.

Fantura, B., Wijaya, I. K. K. A., \& Subamia, I. N. (2020). Implementasi Kebijakan Pemerintah dalam Penataan Parkir Guna Mewudjudkan Tertib Lalu Lintas (Studi Kasus di Kota Labuan Bajo Kabupaten Manggarai Barat). Jurnal Konstruksi Hukum, 1(1), 73-77.

Fatwa Dewan Syariah Nasional MUI No. 108/DSNMUI/X/2016 tentang Pedoman Penyelenggaraan Pariwisata Berdasarkan Prinsip Syariah. (2016). Indonesia.

The Lifestyle and Halal Industry Methods with Local Culture: Study of Tourism and Halal Products in Nusa Tenggara 


\section{Jurnal Ilmiah Al-Syir'ah Vol. 19, No. 1 (2021): 46-70 \\ Website: http://journal.iain-manado.ac.id/index.php/JIS ISSN 2528-0368 (online) ISSN 1693-4202 (print)}

Firmansyah, F., Ramli, R., \& Surdin, S. (2019). Deskripsi Kondisi Sosial Ekonomi Masyarakat di Sekitar Pelabuhan Feri Desa Labuan Bajo Kecamatan Wakorumba Utara Kabupaten Buton Utara. Jurnal Penelitian Pendidikan Geografi, 5(2), 147-155.

Irena, O., Christie, D., \& Thio, S. (2019). Persepsi Masyarakat Terhadap Citra Destinasi dari Candi Borobudur, Mandalika, Labuan Bajo dan Danau Toba. Jurnal Hospitality Dan Manajemen Jasa, 7(2).

Keda, O. (2019). Gubernur NTT Tolak Label Wisata Halal Labuan Bajo. Retrieved from Liputan 6 website: https://www.liputan6.com/regional/read/3959632/gubernur-ntt-tolak-labelwisata-halal-labuan-bajo

Khan, A. M. A., Musthofa, I., Aminuddin, I., Handayani, F., Kuswara, R. N., \& Wulandari, A. (2020). Wisata Kelautan Berkelanjutan di Labuanbajo, Nusa Tenggara Timur: Sebuah Study Tentang Persepsi Masyarakat Kawasan Pesisir. Jurnal Master Pariwisata (JUMPA), 52-76.

Komalasari, F., \& Ganiarto, E. (2019). Determinant Factors Of Indonesian Millennials'revisit Intention: A Case Of Labuan Bajo. FIRM Journal of Management Studies, 4(2), 177-199.

Leha, E., Wolo, D., Marselina, A., \& Parera, R. (2020). Dampak Manajemen Sampah Terhadap Keberlanjutan Pariwisata di Labuan Bajo Kabupaten Manggarai Barat Tahun 2019. Jurnal Kesehatan Masyarakat Dan Lingkungan Hidup, 5(2), 119-145.

Lipka, M. (2017). Muslims and Islam: Key findings in the U.S. and around the world. Retrieved from Pew Research Center website: https://www.pewresearch.org/fact-tank/2017/08/09/muslims-and-islam-keyfindings-in-the-u-s-and-around-the-world/

Mammilianus, S. (2018). Formapp Mabar Menolak Keras Pembangunan Rest Area di Pulau Rinca. Retrieved from Pos Kupang website: https://kupang.tribunnews.com/2018/07/31/formapp-mabar-menolak-keraspembangunan-rest-area-di-pulau-rinca

Maulidi, M. J. (2019). Wisata Halal Dan Identitas Islami: Studi Kasus Lombok, Nusa Tenggara Barat. Jurnal Pemikiran Sosiologi, 6(1), 18-26.

Meo, D. H. N., Sudiarta, I. N., \& Suwena, I. K. (2019). Analisis Kepuasan Wisatawan Mancanegara terhadap Tourist Information Centre di Labuan Bajo. Jurnal IPTA (Industri Perjalanan Wisata), 7(2), 202-210.

MI, \& Lewar, J. (2018). Indahnya Kerukunan di Labuan Bajo. Retrieved from

The Lifestyle and Halal Industry Methods with Local Culture: Study of Tourism and Halal Products in Nusa Tenggara Timur 2020

Ahmad Bahiej, Makhrus Munajat \& Diky Faqih Maulana 


\section{Jurnal Ilmiah Al-Syir'ah Vol. 19, No. 1 (2021): 46-70 \\ Website: http://journal.iain-manado.ac.id/index.php/JIS ISSN 2528-0368 (online) ISSN 1693-4202 (print)}

Media Indonesia website: https://mediaindonesia.com/read/detail/163745indahnya-kerukunan-di-labuan-bajo

Miles, M. B., \& Huberman, A. M. (1994). Qualitative data analysis: An expanded sourcebook. sage.

Muhammad, D. A. (2007). Hukum Islam: Pengantar Ilmu Hukum dan Tata Hukum Islam di Indonesia. Jakarta: Raja Grafindo Persada.

Nations, U. (2002). Johannesburg Summit 2002: International Cooperation to Accelerate Sustainable Development in Developing Countries and Related Domestic Policies. United Nations.

Pambudy, N. M. (2017). Labuan Bajo Permata di Kepulauan Sunda Kecil.

Pratiwi, S. Y. I., \& Pratama, P. (2020). Desain Kapal Wisata dengan Penggunaan Panel Surya di Labuan Bajo. SENSISTEK: Riset Sains Dan Teknologi Kelautan, 3(1), 69-76.

Qardhawi, Y. (1995). Dawr al-Qiyam wa al-Akhlaq fi al-Iqtishad al-Islamiy. Maktabah Wahbah.

Reuters, T., \& Standard, D. (2018). An Inclusive Ethical Economy: State of the Global Islamic Economy Report 2018/19. Dubai: Thomson Reuters.

Rohman, M. (2019). Pariwisata: Potensi Pendongkrak Perekonomian NTT. Badan Pusat Statistik Provinsi Nusa Tenggara Timur. Retrieved from BPS NTT website: $\quad$ https://ntt.bps.go.id/news/2019/07/12/138/-opini--pariwisata-potensi-pendongkrak-perekonomian-ntt.html

Rosana, E. (2015). Konflik pada kehidupan masyarakat (Telaah mengenai teori dan penyelesaian konflik pada masyarakat modern). Al-Adyan: Jurnal Studi Lintas Agama, 10(2), 216-230.

Setiyawan, K. B. (2018). Teori Konflik : Sebuah Kajian Menuju Pemikiran Ralf Dahrendorf. Retrieved from Researchgate website: https://www.researchgate.net/publication/328980540_Teori_Konflik_Sebuah _Kajian_Menuju_Pemikiran_Ralf_Dahrendorf

Soesilowati, E. S., \& Yuliana, C. I. (2013). Komparasi Perilaku Konsumen Produk Halal di Area Mayoritas dan Minoritas Muslim. Jurnal Ekonomi Dan Pembangunan, 21(2), 167-178.

Sugiarto, A., \& Mahagangga, I. G. A. O. (2020). Kendala Pengembangan Pariwisata di Destinasi Pariwisata Labuan Bajo Nusa Tenggara Timur. Jurnal Destinasi Pariwisata, 8(1), 18-25.

Sunarto, K. (2005). Pengantar sosiologi. Universitas Indonesia Publishing.

The Lifestyle and Halal Industry Methods with Local Culture: Study of Tourism and Halal Products in Nusa Tenggara 
Jurnal Ilmiah Al-Syir'ah Vol. 19, No. 1 (2021): 46-70

Website: http://journal.iain-manado.ac.id/index.php/JIS ISSN 2528-0368 (online) ISSN 1693-4202 (print)

Taufiqurrahman, T. (2018). Nembot Penganu Sebagai Kearifan Lokal Suku Paser Perspektif 'Urf. De Jure: Jurnal Hukum Dan Syar'iah, 10(1), 40-48.

Toda, H. (2017). Keanekaragaman Nusa Tenggara Timur Sebagai Provinsi Pariwisata Berkelas Dunia. Jurnal Administrasi Publik, 8(1).

Widianto, S. R., Suryanegara, D., Nababan, Y. R., Bachrodin, I., Ibrahim, A. L., \& Anwar, K. (2019). Pembuatan Peta Wisata Bahari (PWB) Menggunakan Perangkat Lunak Caris Paper Chart Composer 2.1 (Studi Kasus Wilayah Labuan Bajo dan Pulau Komodo). Jurnal HIDROPILAR, 5(1), 35-42.

Wikipedia. (2020). Labuan Bajo, Komodo, Manggarai Barat. Retrieved from Wikipedia website: https://id.wikipedia.org/wiki/Labuan_Bajo,_Komodo,_Manggarai_Barat 